\title{
Solubility of $\mathrm{CaHPO}_{4} \cdot 2 \mathrm{H}_{2} \mathrm{O}$ in the Quaternary System $\mathrm{Ca}(\mathrm{OH})_{2}-\mathrm{H}_{3} \mathrm{PO}_{4}-\mathrm{NaCl}-\mathrm{H}_{2} \mathrm{O}$ at $25{ }^{\circ} \mathrm{C} *$
}

\author{
P. R. Patel, ** T. M. Gregory*** and W. E. Brown $\dagger$ \\ Institute for Materials Research, National Bureau of Standards, Washington, D.C. 20234
}

(August 12, 1974)

\begin{abstract}
Solubility of $\mathrm{CaHPO}_{4} \cdot 2 \mathrm{H}_{2} \mathrm{O}$ was determined in the quaternary system $\mathrm{Ca}(\mathrm{OH})_{2}-\mathrm{H}_{3} \mathrm{PO}_{4}-\mathrm{NaCl}-$ $\mathrm{H}_{2} \mathrm{O}$ at $25^{\circ} \mathrm{C}$ in the $\mathrm{pH}$ range $4.39-6.38$; ionic strengths of the saturated solutions varied from 0.00485 to 0.545 , Satisfactory constancy in the solubility product, $\left(K_{\mathrm{sp}}=\left[\mathrm{Ca}^{2+}\right] \cdot\left[\mathrm{HPO}_{4}^{2-}\right] \cdot \gamma_{\mathrm{Ca}^{2+}} \cdot \gamma_{\mathrm{HPO}_{4}^{2-}}=\right.$ $2.49 \pm 0.05 \times 10^{-7} \mathrm{~mol}^{2} \times 1^{-2}$ ) was obtained when (i) the ion activity coefficients, $\gamma_{i}$, were calculated with the Debye-Hückel equation, $\log \gamma_{i}=-A Z_{i}^{2} \sqrt{ } \bar{I} /\left(1+\mathrm{B} \alpha_{i} \sqrt{I}\right)+0.0626 I$; the value 0.0626 for the coefficient in the linear term was derived from the solubility data by utilizing a statistical procedure, and (ii) formation of an ion pair $\mathrm{NaHPO}_{4}^{-}$was taken into account; a statistically derived value for the stability constant of this ion pair is $7.0 \pm 2.41 \times \mathrm{mol}^{-1}$. The ion pair $\mathrm{NaHPO}_{4}^{-}$appears to have significant concentrations in physiological fluids.
\end{abstract}

Key words: Brushite; $\mathrm{CaHPO}_{4} \cdot 2 \mathrm{H}_{2} \mathrm{O} ; \mathrm{NaHPO}_{4}^{-}$ion pair; solubility product; system $\mathrm{Ca}(\mathrm{OH})_{2}-\mathrm{H}_{3} \mathrm{PO}_{4}-$ $\mathrm{H}_{2} \mathrm{O}-\mathrm{NaCl}$.

\section{Introduction}

The sparingly soluble calcium phosphates, $\mathrm{Ca}_{5}\left(\mathrm{PO}_{4}\right)_{3} \mathrm{OH}, \mathrm{Ca}_{8} \mathrm{H}_{2}\left(\mathrm{PO}_{4}\right)_{6} \cdot 5 \mathrm{H}_{2} \mathrm{O}, \beta-\mathrm{Ca}_{3}\left(\mathrm{PO}_{4}\right)_{2}$, $\mathrm{CaHPO}_{4} \cdot 2 \mathrm{H}_{2} \mathrm{O}$ and $\mathrm{CaHPO}_{4}$ are of considerable physiological interest. For this reason, we have been investigating their solubilities with two major objectives in mind. First, we wish to develop an internally consistent set of thermodynamic quantities-solubility products, enthalpies and entropies of dissolution - for as many of these salts as is feasible experimentally. Second, we wish to try to develop ionic models which will satisfactorily explain the experimental solubility data, and which can subsequently be used to describe the behavior of these salts in physiological systems.

These data were collected at four temperatures $\left(5,15,25,37^{\circ} \mathrm{C}\right)$, over a broad range of concentration (approximately 1000-fold variations in $\mathrm{H}^{+}, \mathrm{Ca}$, and $\mathrm{P}$ concentrations), and for four salts $\left(\mathrm{Ca}_{5}\left(\mathrm{PO}_{4}\right)_{3} \mathrm{OH}\right.$, $\beta-\mathrm{Ca}_{3}\left(\mathrm{PO}_{4}\right)_{2}, \mathrm{CaHPO}_{4} \cdot 2 \mathrm{H}_{2} \mathrm{O}$ and $\left.\mathrm{CaHPO}_{4}\right)$. Nearly all of these measurements were carried out in the ternary system, $\mathrm{Ca}(\mathrm{OH})_{2}-\mathrm{H}_{3} \mathrm{PO}_{4}-\mathrm{H}_{2} \mathrm{O}$, with the objective of using the simplest possible system to assure ease of interpretation of the data [1-6]. ${ }^{1}$ In

* This investigation was supported in part by Research Grant DE00572 to the American Dental Association from the National Institute of Dental Research and is part of the dental research program conducted by the National Bur au of Standards in cooperation with the American Dental Association Health Foundatio ${ }^{\text {. }}$.

** Present address: School of Dentistry, University of Maryland, Baltimore, Md. 21201. *** Research Associate, American Dental Association Health Foundation, Research Unit, National Bureau of Standards, W ashington, D.C. 20234.

† Director, American Dental Association Health Education Foundation, Research Unit, National Bureau of Standards Washington, D.C. 20234

${ }_{1}$ Figures in brackets indicate the literature references at the end of this paper. only one instance was a study made in a quaternary system $\left(\mathrm{Ca}_{5}\left(\mathrm{PO}_{4}\right)_{3} \mathrm{OH}\right.$ in the system $\mathrm{Ca}(\mathrm{OH})_{2}-\mathrm{H}_{3} \mathrm{PO}_{4}-$ $\mathrm{H}_{2} \mathrm{O}-\mathrm{HCl}$ ) [7]. In the present study, solubility measurements were extended to include the physiologically important salt, $\mathrm{NaCl}$, as the fourth component.

In order to calculate the ion activity products a knowledge of ion activity coefficients is required; these are usually calculated with the use of either the Debye-Hückel equation [8], or the Davies equation [9] when the solutions have low ionic strengths. Previous solubility studies on calcium phosphates [1-7] have shown that both of these equations for calculating ion activity coefficients are adequate; the ionic strengths of most of these solutions were less than 0.1 .

The models which satisfactorily account for the above data require the assumption of the presence of the ion pairs $\mathrm{CaHPO}_{4}^{0}$ and $\mathrm{CaH}_{2} \mathrm{PO}_{4}^{+}[1,2]$ in addition to the usual dissociation products of $\mathrm{Ca}(\mathrm{OH})_{2}, \mathrm{H}_{3} \mathrm{PO}_{4}$, and $\mathrm{H}_{2} \mathrm{O}$. In the present work we find it necessary to include the ion pair $\mathrm{NaHPO}_{4}$.

The purposes of the present investigation were (i) to test the usefulness of the expressions for ion activity coefficients in the system $\mathrm{Ca}(\mathrm{OH})_{2}-\mathrm{H}_{3} \mathrm{PO}_{4}$ $\mathrm{NaCl}-\mathrm{H}_{2} \mathrm{O}$ at ionic strengths considerably higher than 0.1 , and (ii) to determine whether or not there is an interaction between the ions of $\mathrm{NaCl}$ with those of $\mathrm{Ca}(\mathrm{OH})_{2}$ and $\mathrm{H}_{3} \mathrm{PO}_{4}$. This was achieved by determination of the solubility of $\mathrm{CaHPO}_{4} \cdot 2 \mathrm{H}_{2} \mathrm{O}$ in the quaternary system over a range of $\mathrm{NaCl}$ concentrations up to $0.5 M$. The salt $\mathrm{CaHPO}_{4} \cdot 2 \mathrm{H}_{2} \mathrm{O}$ was selected for this purpose because (i) it is relatively easy to prepare in 
a pure state, (ii) its relatively high solubility under the most propitious experimental conditions contributes to accuracy in the derived constants, and (iii) our experience indicates that its chemical properties are conducive to rapid attainment of equilibrium between it and the aqueous phase.

\section{Materials and Methods}

\subsection{Materials}

The $\mathrm{CaHPO}_{4} \cdot 2 \mathrm{H}_{2} \mathrm{O}$ used in this study was prepared by bubbling ammonia into an aqueous solution saturated with reagent grade $\mathrm{Ca}\left(\mathrm{H}_{2} \mathrm{PO}_{4}\right)_{2} \cdot \mathrm{H}_{2} \mathrm{O}$ maintained at about $5{ }^{\circ} \mathrm{C}$ [10]; crystals that precipitated in the $\mathrm{pH}$ range 4.0 to 4.2 were collected, washed with distilled water and acetone, air dried, and stored in a refrigerator to prevent dehydration until needed.

The $\mathrm{H}_{3} \mathrm{PO}_{4}$ solutions of various concentrations $\left(\mathrm{P}_{0}\right.$, table 1$)$ were made from doubly crystallized $\mathrm{H}_{3} \mathrm{PO}_{4} \cdot \frac{1}{2} \mathrm{H}_{2} \mathrm{O}$ and freshly boiled distilled water. Known weights of reagent grade $\mathrm{NaCl}$, dried for 24 hours at $125{ }^{\circ} \mathrm{C}$, were dissolved in the $\mathrm{H}_{3} \mathrm{PO}_{4}$ solutions to provide the desired concentrations of $\mathrm{NaCl}$.

\subsection{Solubility Experiments}

Each $2.5 \mathrm{~g}$ sample of $\mathrm{CaHPO}_{4} \cdot 2 \mathrm{H}_{2} \mathrm{O}$ was equilibrated with $200 \mathrm{ml}$ of $\mathrm{NaCl}-\mathrm{H}_{3} \mathrm{PO}_{4}$ solution for two week periods in a thermostated water bath at $25{ }^{\circ} \mathrm{C}$ $\pm 0.01{ }^{\circ} \mathrm{C}$ equipped with an end-over-end rotating device. The equilibrated solutions were filtered through cellulose filters with average pore diameters of $0.24 \mu \mathrm{m}$. The $\mathrm{pH}$ values of the solutions were measured with a research $\mathrm{pH}$ meter which was standardized with NBS certified buffers; the $\mathrm{pH}$ cell was \{glass electrode | test solution $\|$ saturated $\mathrm{KCl} \mid \mathrm{Hg}_{2} \mathrm{Cl}_{2}$; $\mathrm{Hg}\}$; the estimated standard error in the $\mathrm{pH}$ measurements is $\pm 0.01 \mathrm{pH}$ units. Calcium concentrations, $\mathrm{Ca}_{t}$, of the equilibrated solutions were determined with a relative error of 0.025 by means of an atomic absorption spectrophotometer. Phosphorus concentrations, $P_{t}$, were determined to a relative error 0.015 with a double beam spectrophotometer using vanadomolybdate reagent [11].

\subsection{Calculations}

\section{a. Ion-Activity Coefficients}

In most of our calculations, the Debye-Hückel expression, eq (1), was used to evaluate the activity coefficients, $\gamma_{i}$, needed to calculate ion activity products.

$$
\log \gamma_{i}=\left\{-A Z_{i}^{2} \sqrt{I} /\left(1+B \cdot \alpha_{i} \sqrt{I}\right)\right\}+\beta I .
$$

In this equation $A$ and $B$ are temperature dependent constants; $Z_{i}$ is the charge number of the $i$ th ion; $\alpha_{i}$ is its ion-size parameter and $I$ is the ionic strength,

$$
I=\frac{1}{2} \Sigma C_{i} Z_{i}^{2}
$$

TABLE 1. Solubility of $\mathrm{CaHPO}_{4} \cdot 2 \mathrm{H}_{2} \mathrm{O}$ in the system

\begin{tabular}{|c|c|c|c|c|c|}
\hline \multirow{2}{*}{$\begin{array}{l}\text { Solution } \\
\text { No. }\end{array}$} & \multirow{2}{*}{$\begin{array}{l}\mathrm{NaCl} \\
M\end{array}$} & \multicolumn{3}{|c|}{$\begin{array}{l}\text { Equilibrium Composition } \\
\text { of Solutions }\end{array}$} & \multirow{2}{*}{$\frac{\mathrm{C} \mathrm{a}_{t}}{\mathrm{P}_{t}-\mathrm{P}_{0}}$} \\
\hline & & $\mathrm{pH}$ & $\underset{M \times 10^{3}}{\mathrm{Ca}_{i}}$ & $\begin{array}{c}\mathrm{P}_{t} \\
M \times 10^{3}\end{array}$ & \\
\hline \multicolumn{6}{|c|}{$\mathrm{P}_{0}=14.8 M \times 10^{3}$} \\
\hline $\begin{array}{l}A-1 \\
A-2 \\
A-3 \\
A-4 \\
A-5 \\
A-6\end{array}$ & $\begin{array}{r}0.000 \\
.050 \\
.100 \\
.150 \\
.250 \\
.500\end{array}$ & $\begin{array}{l}4.39 \\
4.48 \\
4.54 \\
4.58 \\
4.64 \\
4.70\end{array}$ & $\begin{array}{l}14.7 \\
14.8 \\
14.9 \\
15.0 \\
15.1 \\
15.2\end{array}$ & $\begin{array}{l}29.8 \\
29.8 \\
29.8 \\
29.8 \\
29.8 \\
29.9\end{array}$ & $\begin{array}{r}0.980 \\
.987 \\
.993 \\
1.00 \\
1.01 \\
1.01\end{array}$ \\
\hline \multicolumn{6}{|c|}{$\mathrm{P}_{0}=13.2 M \times 10^{3}$} \\
\hline $\begin{array}{l}B-1 \\
B-4 \\
B-6\end{array}$ & $\begin{array}{r}0.000 \\
.150 \\
.500\end{array}$ & $\begin{array}{l}4.47 \\
4.68 \\
4.80\end{array}$ & $\begin{array}{l}13.2 \\
13.5 \\
14.0\end{array}$ & $\begin{array}{l}26.2 \\
26.3 \\
27.2\end{array}$ & $\begin{array}{l}1.02 \\
1.03 \\
1.00\end{array}$ \\
\hline \multicolumn{6}{|c|}{$\mathrm{P}_{0}=10.5 \mathrm{M} \times 10^{3}$} \\
\hline $\begin{array}{l}C-1 \\
C-2 \\
C-3 \\
C-4 \\
C-5 \\
C-6\end{array}$ & $\begin{array}{r}0.000 \\
.050 \\
.100 \\
.150 \\
.250 \\
.500\end{array}$ & $\begin{array}{l}4.62 \\
4.74 \\
4.81 \\
4.85 \\
4.91 \\
4.97\end{array}$ & $\begin{array}{l}10.6 \\
10.7 \\
10.8 \\
10.9 \\
11.1 \\
11.4\end{array}$ & $\begin{array}{l}21.8 \\
21.9 \\
21.9 \\
21.8 \\
22.0 \\
22.1\end{array}$ & $\begin{array}{r}0.938 \\
.939 \\
.947 \\
.965 \\
.965 \\
.983\end{array}$ \\
\hline \multicolumn{6}{|c|}{$\mathrm{P}_{0}=3.52 M \times 10^{3}$} \\
\hline $\begin{array}{l}D-1 \\
D-2 \\
D-3 \\
D-4 \\
D-5 \\
D-6\end{array}$ & $\begin{array}{r}0.000 \\
.050 \\
.100 \\
.150 \\
.250 \\
.500\end{array}$ & $\begin{array}{l}5.41 \\
5.59 \\
5.66 \\
5.70 \\
5.74 \\
5.79\end{array}$ & $\begin{array}{l}3.74 \\
3.93 \\
4.08 \\
4.24 \\
4.52 \\
4.98\end{array}$ & $\begin{array}{l}7.30 \\
7.47 \\
7.59 \\
7.76 \\
8.02 \\
8.74\end{array}$ & $\begin{array}{l}0.989 \\
.995 \\
1.00 \\
1.00 \\
1.00 \\
0.954\end{array}$ \\
\hline \multicolumn{6}{|c|}{$\mathrm{P}_{0}=1.21 M \times 10^{3}$} \\
\hline $\begin{array}{l}\text { E-1 } \\
\text { E-2 } \\
\text { E-3 } \\
\text { E-4 } \\
\text { E-5 } \\
\text { E-6 }\end{array}$ & $\begin{array}{r}0.000 \\
.050 \\
.100 \\
.150 \\
.250 \\
.500\end{array}$ & $\begin{array}{l}6.19 \\
6.32 \\
6.36 \\
6.37 \\
6.38 \\
6.37\end{array}$ & $\begin{array}{l}1.60 \\
2.06 \\
2.36 \\
2.57 \\
2.93 \\
3.62\end{array}$ & $\begin{array}{l}2.79 \\
3.23 \\
3.51 \\
3.74 \\
4.12 \\
4.82\end{array}$ & $\begin{array}{l}1.01 \\
1.02 \\
1.03 \\
1.02 \\
1.01 \\
1.00\end{array}$ \\
\hline
\end{tabular}
$\mathrm{Ca}(\mathrm{OH})_{2}-\mathrm{H}_{3} \mathrm{PO}_{4}-\mathrm{NaCl}-\mathrm{H}_{2} \mathrm{O}$ at $25^{\circ} \mathrm{C}$

where $C_{i}$ is the molar concentration of an ion. The linear term, $\beta I$, in eq (1) was introduced by Hückel [12] to account for changes in the dielectric constant of the medium as a function of $I$. There is no accepted value for the parameter $\beta$. In all of our previous solubility studies of calcium phosphates [1-7] the value of $\beta$ was set equal to zero, which is appropriate for solutions having low ionic strengths $(<0.1)$.

\section{b. Solubility Product Consfent}

The solubility product constant of $\mathrm{CaHPO}_{4} \cdot 2 \mathrm{H}_{2} \mathrm{O}$ is defined as

$$
\begin{aligned}
K_{\mathrm{sp}}=\left(\mathrm{Ca}^{2+}\right) & \left(\mathrm{HPO}_{4}^{2-}\right) \\
& =\left[\mathrm{Ca}^{2+}\right]\left[\mathrm{HPO}_{4}^{2-}\right] \gamma_{\mathrm{Ca}^{2+}} \cdot \gamma_{\mathrm{HPO}_{4}^{2-}}
\end{aligned}
$$

in which the quantities in parentheses represent molar ion activities and in brackets represent molar concentrations. 
Apparent solubility products, $K_{\mathrm{sp}}^{\prime}$, for each solution were calculated initially from the raw data using a standard iterative procedure [13]; the needed activity coefficients were calculated from eq (1) with $\beta=0$. Values for ionization constants for $\mathrm{H}_{3} \mathrm{PO}_{4}$ and $\mathrm{H}_{2} \mathrm{O}$, the association constants for the ion pairs $\mathrm{CaHPO}_{4}^{0}$ and $\mathrm{CaH}_{2} \mathrm{PO}_{4}^{+}$, and the constants $A$ and $B$ in eq (1) were the same as those used by Gregory et al. [1]. The possible presence of the ion pair $\mathrm{NaHPO}_{4}^{-}$was neglected in the calculation of $\bar{K}_{\text {sp }}^{\prime}$. Henceforth any other quantity calculated in this manner $(\beta=0$ and $\left[\mathrm{NaHPO}_{4}^{-}\right]=0$ ) is indicated as a primed quantity.

Final values of solubility products, $K_{\mathrm{sp}}$, for each solution were calculated similarly, except that statistically derived values for $\beta$ in eq (1) and for $K_{N}$, the stability constant of ion pair $\mathrm{NaHPO}_{4}^{-}$(see sec. 2.3.d), were incorporated into the computations. The stability constant for the ion pair $\mathrm{NaHPO}_{4}^{-}$is defined as

$$
K_{N}=\frac{\left[\mathrm{NaHPO}_{4}\right]^{-} \cdot \gamma_{\mathrm{NaHPO}_{4}^{-}}}{\left[\mathrm{Na}^{+}\right]\left[\mathrm{HPO}_{4}^{2-}\right] \cdot \gamma_{/ \mathrm{Na}+} \cdot \gamma_{\mathrm{HPO}_{4}^{2-}}}
$$

Ion size parameters for $\mathrm{Na}^{+}$and $\mathrm{Cl}^{-}$were taken as 4.0 and 3.0 [14]; the value used for $\mathrm{NaHPO}_{4}, 4.0$, was the same as for $\mathrm{H}_{2} \mathrm{PO}_{4}$. Henceforth, quantities calculated taking into account the estimated values for $\beta$ and $K_{N}$ are denoted by symbols without primes.

\section{c. Electroneutrality Unbalance and Ionic Strength}

For the system $\mathrm{Ca}(\mathrm{OH})_{2}-\mathrm{H}_{3} \mathrm{PO}_{4}-\mathrm{NaCl}-\mathrm{H}_{2} \mathrm{O}$, electroneutrality unbalance is defined here,

$$
U( \pm)=-\sum C_{i} Z_{i}
$$

in which the sum includes the ions $\mathrm{Ca}^{2+} ; \mathrm{H}^{+} ; \mathrm{CaH}_{2}$ $\mathrm{PO}_{4}^{+} ; \mathrm{Na}^{+} ; \mathrm{NaHPO}_{4}^{-} ; \mathrm{OH}^{-} ; \mathrm{Cl}^{-} ; \mathrm{H}_{2} \mathrm{PO}_{4}^{-} ; \mathrm{HPO}_{4}^{2-}$; and $\mathrm{PO}_{4}^{3-}$. Apparent and final values of the unbalances, $U( \pm)^{\prime}$ and $U( \pm)$, as defined in eq (5), and of the ionic strengths, $I^{\prime}$ and $I$, as defined in eq (2), were also calculated.

\section{d. Statistical Evaluation of $\boldsymbol{\beta}, \boldsymbol{K}_{\mathrm{N}}$, and $\boldsymbol{K}_{\mathrm{sp}}^{\circ}$}

Values of the parameter $\beta$ in eq (1), the stability constant of ion pair $\mathrm{NaHPO}_{4}^{-}$, and an "overall" adjusted value of solubility product constant, $K_{\mathrm{sp}}^{0}$, for $\mathrm{CaHPO}_{4} \cdot 2 \mathrm{H}_{2} \mathrm{O}$ were determined from the raw data utilizing a generalized least-squares approach based on the procedure given by Deming [15] and Guest [16]; the application of this method to solubility data of $\mathrm{CaHPO}_{4} \cdot 2 \mathrm{H}_{2} \mathrm{O}$ in the ternary system has been described in detail by Gregory et al. [1].

In brief, the raw data were adjusted giving consideration to the weights of the measurements, so that the sum of squares of the weighted adjustments in the measurements was minimal. The weights were taken as inversely proportional to the squares of the standard errors in the measurements $\left(\mathrm{Ca}_{t} \pm 2.5 \% ; \mathrm{P}_{0}\right.$ and $\mathrm{P}_{t}$ $\pm 1.5 \% ; \quad \mathrm{NaCl} \pm 1.0 \% ; \quad \mathrm{pH} \pm 0.01)$. These adjustments were subjected to the condition that the ad- justed measurements and the final estimated parameters would fulfill the following restrictions of the ionic model (in which the Debye-Hückel equation is used to calculate single-ion activity coefficients):

$$
\begin{gathered}
I^{*}=\frac{1}{2} \sum C_{i}^{*} Z_{i}^{2} \\
\log \gamma_{i}^{*}=\left\{-A Z_{i}^{2} \sqrt{I^{*}} /\left(1+B \alpha_{i} \sqrt{I^{*}}\right)\right\}+\beta I^{*} \\
\frac{\mathrm{Ca}_{t}^{*}}{\mathrm{P}_{t}^{*}-\mathrm{P}_{0}^{*}}=1.0
\end{gathered}
$$

$$
\begin{gathered}
2\left[\mathrm{Ca}^{2+}\right]^{*}+\left[\mathrm{H}^{+}\right]^{*}+\left[\mathrm{CaH}_{2} \mathrm{PO}_{4}^{+}\right]^{*}+\left[\mathrm{Na}^{+}\right]^{*} \\
=\left[\mathrm{OH}^{-}\right]^{*}+\left[\mathrm{NaHPO}_{4}^{-1}\right]^{*}+\left[\mathrm{Cl}^{-}\right]^{*}+\left[\mathrm{H}_{2} \mathrm{PO}_{4}^{-}\right]^{*} \\
+2\left[\mathrm{HPO}_{4}^{2-}\right]^{*}+3\left[\mathrm{PO}_{4}^{3-}\right]^{*} \\
K_{\mathrm{sp}}^{\circ}=\left[\mathrm{Ca}^{2+}\right]^{*} \cdot\left[\mathrm{HPO}_{4}^{2-}\right]^{*} \cdot \gamma_{\mathrm{Ca}^{2+}}^{*} \cdot \gamma_{\mathrm{HPO}}^{*}{ }_{4}^{-} \\
K_{N}=\frac{\left[\mathrm{NaHPO}_{4}^{-}\right]^{*} \cdot \gamma_{\mathrm{NaHPO}_{4}^{-}}^{*}}{\left[\mathrm{Na}^{+}\right]^{*} \cdot\left[\mathrm{HPO}_{4}^{2-}\right]^{*} \cdot \gamma_{\mathrm{HPO}_{4}^{2-}}^{*} \cdot \gamma_{\mathrm{Na}}^{*}}
\end{gathered}
$$

In eqs (6-11), the starred quantities are either the final statistically adjusted measurements or the quantities derived from such values. Equations (8) and (9) are the conditions for dissolution stoichiometry for $\mathrm{CaHPO}_{4} \cdot 2 \mathrm{H}_{2} \mathrm{O}$ and electroneutrality balance for the solutions, respectively.

In a separate, but similar calculation, the Davies equation (eq 12) for obtaining ion-activity coefficients was used instead of the Debye-Hückel equation (eq 7):

$$
\log \gamma_{i}^{*}=\left\{-A Z_{i}^{2} \sqrt{I}^{*} /\left(1+\sqrt{I^{*}}\right)\right\}+\Delta A Z_{i}^{2} I^{*} .
$$

In this equation $\Delta$ is an adjustable parameter. The previously accepted value, 0.2 , for $\Delta$ [9] has been revised [17] to a new value, 0.3 , based on newer compilations of activity data. Nevertheless, an independent estimate for its value was obtained from the present solubility data.

\section{Results}

The compositions of initial and equilibrated solutions, and the dissolution stoichiometry of the solid, $\mathrm{Ca}_{t} /\left(\mathrm{P}_{t}-\mathrm{P}_{0}\right)$, are given in table 1 . The equilibrium $\mathrm{pH}$ values in sets $A, B, C$, and $D$ increased with increasing amounts of $\mathrm{NaCl}$; this is probably due to the effect of increasing ionic strength on the ion activity coefficient of $\mathrm{H}^{+}$. This effect is masked in set $E$ because formation of $\mathrm{NaHPO}_{4}^{-}$has tendency to reduce $\mathrm{pH}$; thus, the net effect of the two counter-balancing processes is a near constancy in $\mathrm{pH}$ in solutions $E-2$ to $E-6$. Calcium and phosphorus concentrations were nearly constant within the sets $A, B$, and $C$; however, appreciable increases in the concentrations were 
observed in the sets $D$ and $E$ with increasing amounts of $\mathrm{NaCl}$. Stoichiometries of the dissolved solid were close to unity for all the sets (last column in table 1) except for small deviations in solutions $C-1$ to $C-5$ and $D-6$.

Statistically derived values of parameters $\beta$ and $\Delta$ in the Debye-Hückel and Davies equations, respectively, and the values of $K_{N}$ and $K_{\mathrm{sp}}^{0}$ obtained with the two models are given in table 2 .

Apparent and final values of ionic strength, electroneutrality unbalance, and solubility product for $\mathrm{CaHPO}_{4} \cdot 2 \mathrm{H}_{2} \mathrm{O}$ are given in table 3 ; these were calculated with the use of the Debye-Hückel equation. Percentage of total phosphorus bound to $\mathrm{Na}^{+}$in the form of the ion pair $\mathrm{NaHPO}_{4}^{-}$is given in the last column of table 3 . Only $I$ values are listed, because $I^{\prime}$ never differed from $I$ by more than 0.5 percent.

TABLE 2. Statistically derived values of parameters in the ion activity coefficient equations, stability constant for $\mathrm{NaHPO}_{4}^{-}$and solubility product constant for $\mathrm{CaHPO}_{4}$. $2 \mathrm{H}_{2} \mathrm{O}$

\begin{tabular}{c|c|c}
\hline \hline $\begin{array}{c}\text { Derived } \\
\text { quantity }\end{array}$ & Debye-Hücker Equation & Davies Equation \\
\hline $\begin{array}{c}\text { Equation } \\
\text { parameter }\end{array}$ & $\beta=0.0626 \pm 0.0054$ & $\Delta=0.228 \pm 0.007$ \\
$K_{N} \times 10^{7}$ & $7.0 \pm 2.41 . \mathrm{mol}^{-1}$ & $9.4 \pm 5.21 . \mathrm{mol}^{-1}$ \\
$K_{\text {sp }}^{0} \times 1 \mathrm{~mol}^{2} .1^{-2}$ \\
\hline
\end{tabular}

iABLE 3. Calculated values of electroneutrality unbalance, ionic strength, solubility product constant, and percent of total phosphorus bound to sodium ions

\begin{tabular}{|c|c|c|c|c|c|c|}
\hline \multirow{3}{*}{$\begin{array}{l}\text { Solution } \\
\text { No. }\end{array}$} & \multicolumn{6}{|c|}{ Ionic Model With Debye-Hückel Equation } \\
\hline & \multicolumn{2}{|c|}{$\beta=0.0 ; K_{N}=0.0$} & \multicolumn{4}{|c|}{$\beta=0.0626 ; K_{N}=7.0$} \\
\hline & $\begin{array}{c}U^{\prime}( \pm) \\
M \times 10^{3}\end{array}$ & $K_{\mathrm{sp}}^{\prime} \times 10^{7}$ & $I, M$ & $\begin{array}{c}U( \pm) \\
M \times 10^{3}\end{array}$ & $K_{\mathrm{sp}} \times 10^{7}$ & $\begin{array}{c}100 \times \\
{\left[\mathrm{NaHPO}_{4}^{-}\right] / \mathrm{P}_{t}}\end{array}$ \\
\hline \multicolumn{7}{|c|}{$\mathrm{P}_{0}=14.8 \mathrm{M} \times 10^{3}$} \\
\hline $\begin{array}{l}\text { A-1 } \\
\text { A-2 } \\
\text { A-3 } \\
\text { A-4 } \\
\text { A-5 } \\
\text { A-6 }\end{array}$ & $\begin{array}{c}0.361 \\
.237 \\
.0936 \\
-.0633 \\
-.190 \\
-.179\end{array}$ & $\begin{array}{l}2.52 \\
2.42 \\
2.39 \\
2.36 \\
2.31 \\
2.11\end{array}$ & $\begin{array}{c}0.0422 \\
.0928 \\
.143 \\
.194 \\
.294 \\
.545\end{array}$ & $\begin{array}{c}0.361 \\
.253 \\
.128 \\
-.00765 \\
-.0870 \\
.0471\end{array}$ & $\begin{array}{l}2.55 \\
2.48 \\
2.49 \\
2.48 \\
2.50 \\
2.44\end{array}$ & $\begin{array}{l}0.0 \\
.051 \\
.11 \\
.18 \\
.34 \\
.74\end{array}$ \\
\hline \multicolumn{7}{|c|}{$\mathrm{P}_{0}=13.2 \mathrm{M} \times 10^{3}$} \\
\hline $\begin{array}{l}\text { B-1 } \\
\text { B-4 } \\
\text { B-6 }\end{array}$ & $\begin{array}{r}-0.194 \\
-.514 \\
-.407\end{array}$ & $\begin{array}{l}2.50 \\
2.39 \\
2.23\end{array}$ & $\begin{array}{c}0.0378 \\
.189 \\
.541\end{array}$ & $\begin{array}{r}-0.193 \\
-.452 \\
-.150\end{array}$ & $\begin{array}{l}2.53 \\
2.51 \\
2.57\end{array}$ & $\begin{array}{l}0.0 \\
.23 \\
.93\end{array}$ \\
\hline \multicolumn{7}{|c|}{$\mathrm{P}_{0}=10.5 \mathrm{M} \times 10^{3}$} \\
\hline $\begin{array}{l}\mathrm{C}-1 \\
\mathrm{C}-2 \\
\mathrm{C}-3 \\
\mathrm{C}-4 \\
\mathrm{C}-5 \\
\mathrm{C}-6 \\
\end{array}$ & $\begin{array}{r}0.670 \\
.653 \\
.517 \\
.263 \\
.152 \\
-.208 \\
\end{array}$ & $\begin{array}{l}2.53 \\
2.49 \\
2.48 \\
2.42 \\
2.39 \\
2.20\end{array}$ & $\begin{array}{c}0.0309 \\
.0815 \\
.132 \\
.182 \\
.283 \\
.534 \\
\end{array}$ & $\begin{array}{l}0.670 \\
.675 \\
.565 \\
.339 \\
.291 \\
.0952\end{array}$ & $\begin{array}{l}2.56 \\
2.55 \\
2.57 \\
2.53 \\
2.58 \\
2.52\end{array}$ & $\begin{array}{l}0.0 \\
.094 \\
.21 \\
.34 \\
.63 \\
1.4\end{array}$ \\
\hline \multicolumn{7}{|c|}{$\mathrm{P}_{0}=3.52 \mathrm{M} \times 10^{3}$} \\
\hline $\begin{array}{l}\text { D-1 } \\
\text { D-2 } \\
\text { D-3 } \\
\text { D-4 } \\
\text { D-5 } \\
\text { D-6 } \\
\end{array}$ & $\begin{array}{l}0.0330 \\
.00260 \\
-.0502 \\
-.0912 \\
-.224 \\
-.0743 \\
\end{array}$ & $\begin{array}{l}2.44 \\
2.41 \\
2.38 \\
2.37 \\
2.32 \\
2.30\end{array}$ & $\begin{array}{c}0.0110 \\
.0613 \\
.112 \\
.163 \\
.264 \\
.515\end{array}$ & $\begin{array}{c}0.0332 \\
.0497 \\
.0525 \\
.0705 \\
.0540 \\
.511\end{array}$ & $\begin{array}{l}2.45 \\
2.44 \\
2.42 \\
2.43 \\
2.40 \\
2.47\end{array}$ & $\begin{array}{l}0.0 \\
.65 \\
1.4 \\
2.2 \\
3.8 \\
7.6\end{array}$ \\
\hline \multicolumn{7}{|c|}{$\mathrm{P}_{0}=1.21 \mathrm{M} \times 10^{3}$} \\
\hline $\begin{array}{l}\text { E-1 } \\
\text { E-2 } \\
\text { E-3 } \\
\text { E-4 } \\
\text { E-5 } \\
\text { E-6 }\end{array}$ & $\begin{array}{l}-0.0488 \\
-.192 \\
-.299 \\
-.336 \\
-.424 \\
-.676\end{array}$ & $\begin{array}{l}2.52 \\
2.50 \\
2.57 \\
2.55 \\
2.56 \\
2.59\end{array}$ & $\begin{array}{l}0.00485 \\
.0564 \\
.107 \\
.158 \\
.259 \\
.511\end{array}$ & $\begin{array}{c}-0.0488 \\
-.119 \\
-.155 \\
-.128 \\
-.0976 \\
-.0959\end{array}$ & $\begin{array}{l}2.52 \\
2.47 \\
2.51 \\
2.46 \\
2.45 \\
2.44\end{array}$ & $\begin{array}{r}0.0 \\
2.9 \\
5.5 \\
7.7 \\
11.6 \\
18.7\end{array}$ \\
\hline
\end{tabular}

Average $K_{\mathrm{sp}}=2.49 \pm 0.05 \times 10^{-7} \mathrm{~mol}^{2} .1^{-2}$ 


\section{Discussion}

Calculation of ion activity products for solutions of calcium phosphates with ionic strengths of about 0.16 is of interest to investigators involved in the study of biological calcification. In dilute calcium phosphate systems $(I<0.1)$, the Debye-Hückel and the Davies expressions $(\beta=0.0$ or $\Delta=0.3)$ have given consistently reliable ion activity products as judged by the constancy of the solubility products in solutions saturated with respect to solid phases such as $\mathrm{CaHPO}_{4} \cdot 2 \mathrm{H}_{2} \mathrm{O}$ [1], $\mathrm{CaHPO}_{4}[2], \beta-\mathrm{Ca}_{3}\left(\mathrm{PO}_{4}\right)_{2}$ [3], and $\mathrm{Ca}_{5}\left(\mathrm{PO}_{4}\right)_{3} \mathrm{OH}$ [4-7]. The data presented here test the applicability of these expressions for solutions with ionic strengths in the range $0.005-0.55$. These data also show that significant concentrations of the ion pair $\mathrm{NaHPO}_{4}^{-}$form at high concentrations of $\mathrm{Na}^{+}$and at higher $\mathrm{pH}$ 's; this obviously has considerable significance relative to the activities of phosphate ions in fluids such as blood.

\subsection{Solubility Product Constant}

The data presented in table 3 and figures $1 \mathrm{a}$ and $2 \mathrm{a}$ show that at higher values of $I$ the Debye-Hückel
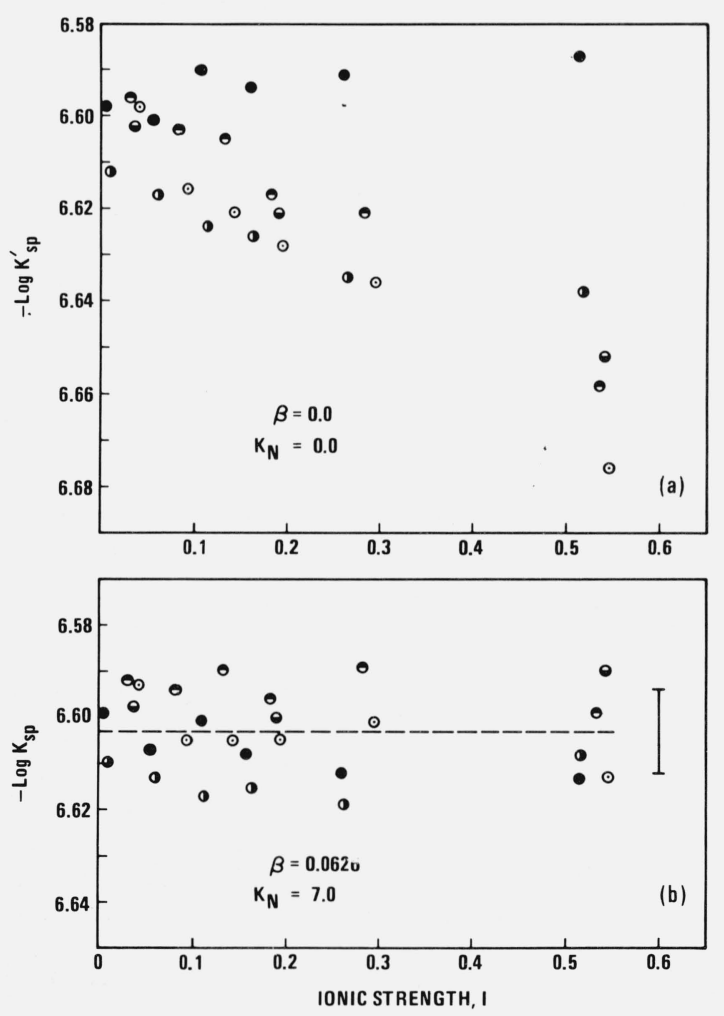

Figure 1. (a) Plot of $-\log \mathrm{K}_{\mathrm{sp}}^{\prime}$ versus ionic strength; Debye-Hückel equation with $\beta=0.0$ was used and ion pair $\mathrm{NaHPO}_{4}^{-}$was omitted from the calculations.

Key for the symbols: $\odot$ Set A; $\odot$ Set B; $\odot$ Set $\mathrm{C}$; Set $\mathrm{D}$; and $\odot$ Set $\mathrm{E}$ ot table 3. (b) Plot of $-\log \mathrm{K}_{\mathrm{sp}}$ versus ionic strength; the Debye-Hückel equation with $\beta=0.0626$ and the value 7.0 for the stability constant of the ion pair $\mathrm{NAHPO}_{4}^{-}$were used in the calculations.

The broken line corresponds to a mean $-\log K_{\mathrm{sp}}$ value of 6.603 ; the standard error in the $-\log K_{\mathrm{sp}}$ values $( \pm 0.009)$ is shown by the bar to the right of the points. equation $(\beta=0)$ and the Davies equation $(\Delta=0.3)$ do not give constant $p K_{\mathrm{sp}}^{\prime}$; instead these products decrease (figure la) or first decrease and then increase (figure 2a) as a function of increasing ionic strength. We attribute these deviations (i) to failure of the DebyeHückel and Davies expressions with $\beta=0$ and $\Delta=0.3$, respectively, at high ionic strengths, and (ii) to formation of the ion pair $\mathrm{NaHPO}_{4}^{-}$.

The final adjustments required to fulfill the restrictions of the ionic model (eqs 6-11) with Debye-Hückel activity coefficients were, in general, within the standard errors of the measurements and were randomly positive and negative. However, for solutions $C-1$ to $C-5$, the adjustments for phosphorus concentrations were all negative $(-2.6,-2.6$, $-2.4,-1.6$, and $-1.9 \%$ respectively) and larger than the standard error, 1.5 percent. Solution $D-6$ required a large positive adjustment $(3.8 \%)$ in the calcium measurement (standard error $2.5 \%$ ). Slightly abnormal dissolution stoichiometries in these particular solutions (table 1) are explainable on the basis of the possible systematic errors in the phosphorus concentrations for the solutions $C-1$ to $C-5$ and in the calcium concentration for the solution $D-6$.

The results of the final adjustments obtained with the Davies expression (eqs (6) and (8-12)), although not listed, were similar to those described above and the same conclusions can be drawn from them.

Plots of $p K_{\mathrm{sp}}^{\prime}\left(-\log K_{\mathrm{sp}}^{\prime}\right)$ and $p K_{\mathrm{sp}}\left(-\log K_{\mathrm{sp}}\right)$ against ionic strength are given in figures 1 and 2 for calculations made with the Debye-Hückel and Davies equations, respectively.

When the statistically estimated value $(0.0626)$ for the parameter $\beta$ is used in the linear term of the DebyeHückel equation and when the presence of $\mathrm{NaHPO}_{4}^{-}$ is incorporated into the calculations, the final values of $p K_{\mathrm{sp}}$ show greatly improved constancy (fig. lb). Note especially that the trend in the points apparent in figure la, is eliminated; the scatter of the points of series $E$ (filled circles) is reduced through the incorporation of the ion pair $\mathrm{NaHPO}_{4}^{-}$into the model.

The positive value of the parameter $\beta$ obtained in this study (table 2) is in accord with the view that an increase in $I$ decreases the dielectric constant of the medium, as was shown for 14 other electrolyte systems by Hasted et al. [19]. Moreno et al. [10] reported a value $(-0.082)$ for $\beta$ in their solubility experiments with $\mathrm{CaHPO}_{4} \cdot 2 \mathrm{H}_{2} \mathrm{O}$ in $\mathrm{H}_{3} \mathrm{PO}_{4}$ solutions containing $\mathrm{NaCl}$. However, only three solutions containing $\mathrm{NaCl}$ were used in their study; the maximum $\mathrm{NaCl}$ concentration was only $0.1045 \mathrm{M}$, and the presence of ion pairs between calcium and phosphate species was not taken into account. However, we recalculated their data, taking into account the presence of the ion pairs $\mathrm{CaHPO}_{4}^{0}$ and $\mathrm{CaH}_{2} \mathrm{PO}_{4}^{+}$, with the finding that the $K_{\text {sp }}$ became essentially constant and $\beta$ in the DebyeHückel expression became non-determinant.

Robinson and Stokes [20] have used a value of $\beta=0.055$ in the Debye-Hückel equation to describe experimental values of activity coefficients of $\mathrm{NaCl}$ solutions up to $2 M$; the value, 0.0626 , obtained in this study compares reasonably well with theirs. 
Our value (table 2) for $K_{\mathrm{sp}}^{0}, 2.48 \pm 0.02 \times 10^{-7}$, obtained with $\beta=0.0626$ compares well with the value, $2.56 \pm 0.05 \times 10^{-7}$, obtained by Gregory et al [1] through use of a similar statistical treatment of data (except that $\beta$ was set equal to zero) for the ternary system in which the ionic strengths were too small for the term $\beta I$ to make a significant difference.

Similar calculations of $K_{\mathrm{sp}}^{\prime}$ and $K_{\mathrm{sp}}$ were also made with the Davies equation; these results are shown in figure 2 . In this case, the $p K_{\mathrm{sp}}^{\prime}$ values decreased as a function of $I$, up to $I=0.18$ and then increased rapidly. The $p K_{\mathrm{sp}}$ values obtained with the Davies equation (fig. $2 \mathrm{~b}$ ), contrary to those in figure $1 \mathrm{~b}$ obtained with the Debye-Hückel equation, show an apparent trend. For this reason, the Debye-Hückel expression with $\beta=0.0626$ appears to be preferable to the Davies equation, at least for this system. It should be noted that the persisting trend in figure 2 may be due to the absence of the ion size parameters, $\alpha_{i}$, in the Davies equation.

\subsection{Electroneutrality Unbalances}

Theoretically, the electroneutrality unbalances, $U( \pm)^{\prime}$ and $U( \pm)$ should be zero. However, in prac-
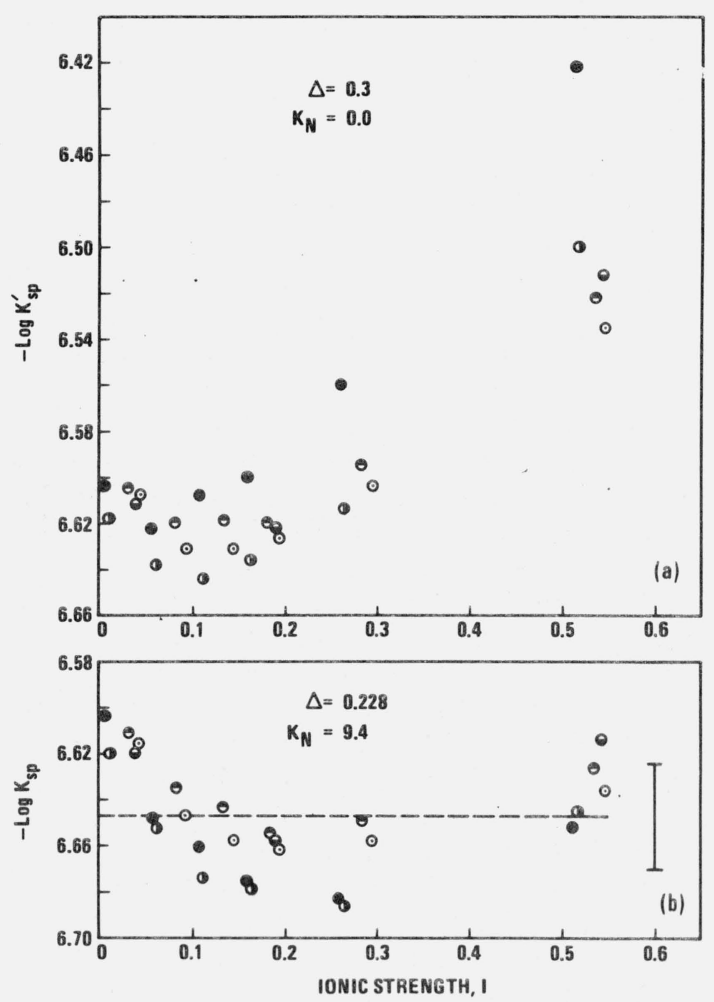

Figure 2. (a) Plot of $-\log \mathrm{K}_{\mathrm{sp}}^{\prime}$ versus unic strength; Davies equation with $\Delta=0.3$ was used and the ion pair $\mathrm{NaHPO}_{4}^{-}$were used in the calculations.

Key for the symbols: Same as in figure 1.

(b) Plot of $-\log \mathrm{K}_{\mathrm{sp}}$ versus ionic strength; the Davies equation with $\Delta=0.228$ and a value of 9.4 for the stability constant of the ion pair $\mathrm{NaHPO}_{4}^{-}$were used in the calculations.

The broken line corresponds to a mean - $\log K_{\text {sp }}$ value of 6.647; the standard error in the $-\log K_{\mathrm{sp}}$ values $( \pm 0.023)$ is shown by the bar to the right of the points. tice there are at least four reasons why the unbalances differ from zero. (1) Experimental errors in the $\mathrm{pH}$, and concentrations of calcium and phosphorus are always present; (2) the presence of unknown ionic impurities are not taken into account in the calculation of unbalances; (3) an ionic species such as $\mathrm{NaHPO}_{4}^{-}$may be omitted from the working model even though it may have a significant concentration; and (4) errors in the relative concentrations of the various phosphate ions may result from the use of incorrect dissociation constants or from deficiencies in the expressions for activity coefficients.

The unbalances listed in table 3 are small and random in sign for the sets $A$ and $B$. The apparent trend in $U( \pm)^{\prime}$ in the sets $D$ and $E$-almosi all values are negative and increasing with increasing amounts of ion pair formation - is attributed to the omission of the ion pair $\mathrm{NaHPO}_{4}^{-}$in calculation of the values of $U( \pm)^{\prime}$; the corresponding $U( \pm)$ values, which take into account the ion pair $\mathrm{NaHPO}_{4}^{-}$, do not show this trend, and, thus support the existence of that ion pair. The abnormal value of the unbalance in solution $D-6$ and a trend in the unbalance of solutions $C-1$ to $C-5$ may be caused by experimental errors as mentioned in the section 3. The inclusion of the linear term $(0.0626 \mathrm{I})$ in the Debye-Hückel equation does not change the $U( \pm)^{\prime}$ values significantly.

\subsection{Dissolution Stoichiometry}

The dissolution stoichiometry of $\mathrm{CaHPO}_{4} \cdot 2 \mathrm{H}_{2} \mathrm{O}$. $\mathrm{Ca}_{t} /\left(\mathrm{P}_{t}-\mathrm{P}_{0}\right)$ should be 1.0. In most of the cases (table 1) this stoichiometry is close to 1.0 and within the standard error \pm 0.03 .

\subsection{Metastability With Respect to Other Calcium Phosphates}

All the equilibrated solutions in this study were supersaturated with respect to $\mathrm{Ca}_{5}\left(\mathrm{PO}_{4}\right)_{3} \mathrm{OH}$ (solubility product constant $\left.=4.8 \times 10^{-59}[5-7]\right)$; the activity products $\left(\mathrm{Ca}^{2+}\right)^{5} \quad\left(\mathrm{PO}_{4}^{3-}\right)^{3} \quad\left(\mathrm{OH}^{-}\right)$, varied from $2.7 \times 10^{-58}$ in $A-1$ to $3.6 \times 10^{-52}$ in $E-6$. The solutions $A-1$ to $D-6$ were undersaturated, and the solutions $E-1$ to $E-6$ supersaturated, with respect to $\beta-\mathrm{Ca}_{3} \quad\left(\mathrm{PO}_{4}\right)_{2} \quad$ (solubility product constant $=1.4$ $\left.\times 10^{-29}[3]\right)$; the activity product, $\left(\mathrm{Ca}^{2+}\right)^{3}\left(\mathrm{PO}_{4}^{3-}\right)^{2}$, varied from $5.5 \times 10^{-32}$ to $6.1 \times 10^{-30}$ in $A-1$ to $D-6$ and $3.5 \times 10^{-29}$ to $6.31 \times 10^{-29}$ in $E-1$ to $E-6$. All the solutions were undersaturated with $\mathrm{Ca}_{8} \mathrm{H}_{2}\left(\mathrm{PO}_{4}\right)_{6} \cdot 5 \mathrm{H}_{2} \mathrm{O}$ (solubility product constant $=1.1 \times 10^{-94}[18]$ ); the activity product, $\left(\mathrm{Ca}^{2+}\right)^{8}\left(\mathrm{H}^{+}\right)^{2}\left(\mathrm{PO}_{4}^{3-}\right)^{6}$, varied from $4.1 \times 10^{-101}$ to $4.9 \times 10^{-95}$ in $A-1$ to $E-6$. The above activity products were calculated with the Debye: Hückel equation $\left(\beta=0.0626\right.$ and $\left.K_{N}=7.0\right)$.

Thus the solubility study reported here involvec metastable equilibria; this situation also existed ir previous solubility studies with $\mathrm{CaHPO}_{4} \cdot 2 \mathrm{H}_{2} \mathrm{O}$ [1] $\mathrm{CaHPO}_{4}[2]$, and $\beta-\mathrm{Ca}_{3}\left(\mathrm{PO}_{4}\right)_{2}$ [3]. The effects o1 crystallization of $\mathrm{Ca}_{5}\left(\mathrm{PO}_{4}\right)_{3} \mathrm{OH}$ or $\beta-\mathrm{Ca}_{3}\left(\mathrm{PO}_{4}\right)_{2}$ 
during the solubility experiments are not important because of very slow growth rates of these salts. Significant precipitation of other calcium phosphate salt in the solution would cause deviations in the apparent dissolution stoichiometry of $\mathrm{CaHPO}_{4} \cdot 2 \mathrm{H}_{2} \mathrm{O}$. However, the values of $U( \pm)^{\prime}$ and $U( \pm)$ would not be affected. Even though the greatest potential for precipitation of $\mathrm{Ca}_{5}\left(\mathrm{PO}_{4}\right)_{3} \mathrm{OH}$ or $\beta-\mathrm{Ca}_{3}\left(\mathrm{PO}_{4}\right)_{2}$ is in solutions $E-1$ to $E-6$, close to ideal stoichiometry of dissolution is observed in these solutions, confirming the earlier conclusion that the deviations in $C-1$ to $C-5$ and $D-6$ must have been caused by factors other than precipitation of other calcium phosphate salts.

\subsection{Formation of the lon Pair $\mathrm{NaHPO}_{4}^{-}$}

Formation of this ion pair should become significant at high $\mathrm{Na}^{+}$and $\mathrm{HPO}_{4}^{-}$activities. Percentages of total phosphorus in the form of this ion pair are given in the last column of table 3 . It is seen that a maximum of 19 percent of the phosphorus is bound in the form of this ion pair (solution $E-6$ ). For comparison, a serum with $\mathrm{Na}^{+}=0.140 M, \mathrm{Ca}_{t}=2.45 \times 10^{-3} M, \mathrm{P}_{t}=1.33$ $\times 10^{-3} M, \mathrm{pH}=7.4$ and $I=0.16$ would have about 18 percent of its phosphorus in the form $\mathrm{NaHPO}_{4}^{-}$. This, of course, would be a maximum value because of the presence of other ion pairs and complexes, but this calculation reveals that this ion pair should be given consideration.

The stability constant obtained with the Davies equation, 9.4 \pm 5.2 , (table 2), for $\mathrm{NaHPO}_{4}^{-}$, is within the limits of error of that obtained with the Debye-Hückel equation, $7.0 \pm 2.4$.

An "apparent" stability constant value, 4.0, was reported by Smith and Alberty [21] in a study carried out at constant ionic strength of 0.2 . Through the use of this ionic strength and the Debye-Hückel equation $(\beta=0.0626)$, a corrected value 18 is obtained. This cannot be compared directly with our value 7.0 because its uncertainty is not known, but at least it has the same order of magnitude.

Formation of this ion pair would increase the dissolution of a calcium phosphate in a sodium-containing solution. This is apparent in the increases in the concentrations of calcium and phosphorus with $\mathrm{NaCl}$ concentration in Sets $D$ and $E$ as compared to sets $A$ to $C$ (table 1).

The greater formation of this ion pair in set $\boldsymbol{E}$, as compared to sets $A$ to $C$. is also manifested by the fact that the $\mathrm{pH}$ increases with increasing ionic strength much less slowly in set $E$ than in the other sets. Here, formation of the ion pair $\mathrm{NaHPO}_{4}^{-}$has the effect of increasing the overall dissociation of the phosphoric acid. Thus, the presence of this ion pair may have a significant role in physiological processes.

The authors thank E. M. S. Miletta for technical assistance.

\section{References}

[1] Gregory, T. M., Moreno, E. C., and Brown, W. E., J. Res. Nat. Bur. Stand. (U.S.), 74A, (Phys. and Chem.), No. 4, 461-475 (July-Aug., 1970).

[2] McDowell, H., Brown, W. E., and Sutter, J. R., Inorg. Chem. 10, 1638-1643 (1971).

[3] Moreno, E. C., Patel, J. M., Gregory, T. M., and Brown, W. E., Abstracted Internatl. Assoc. Dent. Res. Program and Abstracts of Papers No. 183, 1970.

[4] Moreno, E. C., Gregory, T. M., and Brown, W. E., J. Kes. Nat. Bur. Stand. (U.S.), 72A, (Phys. and Chem.), No. 6, 773-782 (Nov.-Dec. 1 Y̌óó).

[5] Avnimelech, Y., Moreno, E. C., and Brown, W. E., J. Res. Nat. Bur. Stand. (U.S.), 77A, (Phys. and Chem.), No. 1, 149-155 (1973).

[6] McDowell, H., Wallace, B. M. and Brown, W. E., Abstracted Internatl. Assoc. Dent. Res. Program and Abstracts of Papers, No. 340, 1969.

[7] Chuong, R., J. Dental Res., 52, 911-914 (1973).

[8] Debye, P. and Hückel, E., Phys. Z. 24, 185-206 (1923).

[9] Davies, C. W., J. Chem. Soc. (London) 2093-2098 (1938).

[10] Moreno, E. C., Brown, W. E., and Osborn, G., Soil Science Society of America Proceedings 24, 94-98 (1960).

[11] Brabson, J. A., Dunn, R. L., Epps, E. A. Jr., Hoffman, W. M. and Jacob, K. D., J. Assoc. Official Agricultural Chemists 41, 517-524 (1958).

[12] Hückel, E., Phys. Z. 26, 93-147 (1925).

[13] Moreno, E. C., Gregory, T. M., and Brown, W. E., J. Res. Nat. Bur. Stand. (U.S.), 70A, (Phys. and Chem.), No. 6, 545-552 (Nov.-Dec. 1966).

[14] Kielland, J., J. Am. Chem. Soc. 59, 1675-1678 (1937).

[15] Deming, W. E., Statistical Adjustment of Data, pp. 49-58 (John Wiley and Sons, Inc., New York, N.Y., 1943). (Reprinted by Dover Publications, New York, N.Y., 1964).

[16] Guest, P. G., Numerical Methods of Curve Fitting, pp. 370-381 (Cambridge University Press, Cambridge, England, 1961).

[17] Davies, C. W., Ion Association (Butterworth and Co., Ltd. London, England, 1962).

[18] Moreno, E. C., Brown, W. E., and Osborn, G., Soil Science Society of American Proceedings 24, 99-102 (1960).

[19] Hasted, J. B., Ritson, D. M., and Collie, C. H., J. Chem. Phys. 16, 1-21 (1948).

[20] Robinson, R. A. and Stokes, R. H. Electrolyte Solutions, pp. 236-237 (Butterworth and Co., Ltd., London, England, 1959 [Sec. Edition]).

[21] Smith, R. M. and Alberty, R. A., J. Phys. Chem. 60, 180-184 (1956).

(Paper 78A6-840) 